Page: 351-361 ISBN: 978-602-6 988-75-1

Web Jurnal Online: jurnal.unmuhjember.ac.id

By: Rina Susanti Hartono

The Village Government Administration Implementation In Supporting Village

Community And Development Service In Bekasi District

\title{
THE VILLAGE GOVERNMENT ADMINISTRATION IMPLEMENTATION IN SUPPORTING VILLAGE COMMUNITY AND DEVELOPMENT SERVICE IN BEKASI DISTRICT
}

\author{
Rina Susanti Hartono \\ (rinasusanti.h@gmail.com) \\ Unisma Bekasi
}

\begin{abstract}
Since the enactment of Law number 6 of 2014 concerning the village, it has been giving a new motivation to the village to increase its creativity in increasing the public service and increased development in the village. This village's motivation is influenced by bigger support from the government in creating the village establishment as an implementation of the third Nawacita that states "Building Indonesia from the suburbs by strengthening the areas and villages in the framework of the unitary state". The real indication can be seen from the launch of so many funds for the village from the government in order to realize the acceleration in the development of rural communities. This support must be followed by the orderly village's government administrations in order to create the village's accountability itself and the truth has gotten from the rural communities to their village's government. This research is done in the whole subdistricts in Bekasi district by taking the sample of one village per one sub-district. The aim of this research is to know the village government administration implementation based on the Minister of Home Affair Regulation number 47 in 2016 in supporting the community services and villages' establishment. The research method that is used is the qualitative method with the aim to gain the learned problems. The informant decided on this research is the Village' secretary who represents the village government staffs for each sub-district, the Village Consultative Institution, Sub-district staffs, and the regional staffs who handle the village.
\end{abstract}

Keywords: Implementation, Village government administration, Public service 
Page: 351-361 ISBN: 978-602-6 988-75-1

Web Jurnal Online: jurnal.unmuhjember.ac.id

By: Rina Susanti Hartono

The Village Government Administration Implementation In Supporting Village

Community And Development Service In Bekasi District

\section{INTRODUCTION}

Based on Law Number 6 of 2014 concerning Villages which is a development of Law No. 32 of 2004 concerning Regional Government (currently it has been refined into Law Number 23 of 2014) where villages require separate arrangements, but the process of decentralization needs to be optimized by improving the process of accelerating village development through optimizing village administration. This is to support the smooth operation of the basic tasks and benefits of Village Government Administration in Improving Community Services in Bekasi District. Village Government Administration is a service process carried out by the Village Head and Village Equipment which aims to capture the village community in Bekasi Regency. In this case, government support with the launch of village funds provided high motivation for the implementation of village government administration.

Seen from the division of the district, the village and urban village referred to are part of the Regency/city government, this matter has also been arranged in Law Number 23 of 2014, where the village is directly under the Sub-district and is directly responsible to the sub-district head. This is in the form of Government Regulation Number 72 of 2005 Regarding Village Government is the government's efforts to realize public welfare evenly and can provide excellent service for the community. This was manifested as stated in Law Number 6 Year 2014 concerning Villages which is a legal community unit that has a district boundary that has the authority to organize and manage government matters, the interests of the local community, according to community initiatives, origin rights, and / or traditional rights declared and respected in the system of government of the Unitary State of the Republic of Indonesia.

Therefore the village government is the focal point from the establishment where the village government is the lowest government institution and it has the small range of area; so that it is hoped that the village government can absorb all the residents' aspiration. Through the right village government administration implementation it is hoped that the village government can administer well so that the equitable development and the excellent service for the public can be implemented optimally.

In the framework of extensive implementation and responsible regional autonomy, in Bekasi Regency, it is carried out by first compiling the village administration. The formation of village government is based on community participation by integrating traditional values and principles of modern organizations.

\section{THEORITICAL REVIEW}

\subsection{Administration}

Etymologically, 'administration' derives from the word Ad- and ministrate which means: serving, helping, fulfilling, implementing, applying, controlling, organizing, directing, producing, managing, driving, managing, managing, managing, and utilizing. Whereas in French, it is called the word Administer. From this word formed nouns namely Administratio and adjectives Administratius which in English translated as Administration. 
Page: 351-361 ISBN: 978-602-6 988-75-1

Web Jurnal Online: jurnal.unmuhjember.ac.id

By: Rina Susanti Hartono

The Village Government Administration Implementation In Supporting Village

Community And Development Service In Bekasi District

According to Sondang P Siagian, 'administration' defines as the whole cooperation process between two people or more that is based on certain rationality to reach an aim made before, (Syafri, M.si, 2012: A study about public administration). Next is Widjaja (2002:87) who states that administration is an act of implementing in each cooperation effort between the groups of people to reach a certain aim. Administration can be also translated as the whole set of arrangements for the main work carried out by a group of people in cooperation reaching a certain goal. The most important administration for humans to support every work carried out in cooperation reaches a certain goal. The most important administration is for humans where it supports every work done in relation to their social environment. Given the importance of administration at this time according to the above definition, it can be decided that the administrative characteristics are as follows:

a. Done by the groups of people or it is done by more than just a person

b. There is vertical and horizontal cooperation.

c. There is a clear division of task and

d. The existence of facilities and infrastructure that support the implementation of tasks

e. The existence of aim that wants to be reached

\subsection{Government}

The government in a wide meaning has an obligation to take care of peace and the state peace; both inside and outside. That is why; the first thing to do is that a government has to own the military power or skill to control the army. The second thing to own is the legislative power or in the area of making the law. The third thing to have is the financial strength or ability finance the communities in organizing regulations; which means organizing the state interests.

According to Syafiie (2003:136) he states that Government is how to carry out the arrangement (executive), regulation (legislative), leadership and government coordination (center or with any regions or the leader with his residents) in a lot of government events and phenomena that is hoped to do in the right and proper way.

\subsection{Village}

Based on the information from the Law of the Republic of Indonesia Number 6 of 2014 concerning Villages, it is stated that Villages are the legal community units that have district boundaries that are authorized to regulate and manage government, community interests, origin rights, and/or traditional rights that are declared and respected in the system of government of the Unitary State of the Republic of Indonesia.

\subsection{The Vllage Government Administratio.}

Government Administration in the Republic of Indonesia is regulated in Law No. 30 of 2014 concerning Government Administration, the law clearly explains the rules and procedures in the supervision of existing state apparatus in each region, and the rules of the regulation are a form of government contribution in monitoring every violation committed by the State apparatus. The implementation of these legal products is carried 
Proceeding ICOGISS 2019

Page: 351-361 ISBN: 978-602-6 988-75-1

Web Jurnal Online: jurnal.unmuhjember.ac.id

By: Rina Susanti Hartono

The Village Government Administration Implementation In Supporting Village

Community And Development Service In Bekasi District

out at the village level, where Law No. 6 of 2014 concerning Villages clearly regulates the administration of Village Government, Law No. 6 of 2014 Chapter VII Article (69) concerning Village Regulations which basically regulates Village Regulations to support the existing development of the Village. The implementation and discussion of these regulations are discussed together to reach an agreement together with involving all elements of society .

In the process of implementing Village Government Administration through Minister of Home Affairs Regulation No. 47 of 2016 Chapter II Article (2), explained the processes and administrative arrangements in the village that cover the General Administration, Administration Location, Financial Administration, Development Administration, Other Administration. The implementation of Village Administration is a manifestation of the central government in realizing good and targeted governance. To organize Administration Government Administration which is in the Republic of Indonesia is regulated in Law No. 30 of 2014 concerning Government Administration, the law clearly explains the rules and procedures in the supervision of existing state apparatus in each region, and the rules of the regulation are a form of government contribution in monitoring every violation committed by the State apparatus. The implementation of these legal products is carried out at the village level, where Law No. 6 of 2014 concerning Villages clearly regulates the administration of Village Government, Law No. 6 of 2014 Chapter VII Article (69) concerning Village Regulations which basically regulates Village Regulations to support the existing development of the Village. The implementation and discussion of these regulations were discussed together to achieve joint agreements involving all elements of society.

To implement an effective Village Government administration, guidance and supervision is required by the District Government on village government officials in the process of administering the government, so that village officials can carry out their duties and obligations in serving the community. This is regulated in Article 6 Paragraph (3) of the Minister of Home Affairs Regulation Number 32 of 2006 concerning Village Administration Guidelines which was later amended to become Minister of Home Affairs Regulation No. 47 of 2016.

The attention of the Central Government towards the development of more and more regions is strengthened by the existence of Village Funds which are given to villages in Indonesia. The Village Funds are continuously optimized through Ministerial Regulation No. 16 of 2018 concerning Priority for the Use of Village Funds so that there is a reduction in fraud.

Through Permen No. 16 of 2018 issued by the Minister of Village, Development of Dis advantaged Regions, and Transmigration of the Republic of Indonesia, the Village Fund has a number of priorities covered by 3 Paragraphs in Article 4. The priority is expected that the village has direction and views on the utilization of the Village Fund. Priority for the Use of Village Funds as an effort to improve public services at the village level is further explained in Article 6 of Permen No. 16 of 2018 which describes a number of activities in the health sector which include the provision of clean water and sanitation, provision of supplementary food for infants and toddlers, to training in the 
Page: 351-361 ISBN: 978-602-6 988-75-1

Web Jurnal Online: jurnal.unmuhjember.ac.id

By: Rina Susanti Hartono

The Village Government Administration Implementation In Supporting Village

Community And Development Service In Bekasi District

supervision of health development of pregnant women or nursing mothers as well as a number of other activities.

\section{RESEARCH METHODOLOGY}

\subsection{Types of Research}

The type of this research uses the descriptive qualitative research wherein this research work researcher did the description of the situation on the field and explained it in detail. Based on the information from Arikunto (2005) descriptive research is a research that is made to collect information about an existing phenomena status; those are the phenomena based on the real information when the research was done.

\subsection{The Location of Research}

The location of this research are some villages in Bekasi Districts.

\subsection{Data Source}

\subsubsection{Primary Data.}

Primary data is a data gotten from interviewees by having the question-answer technique directly and it is given the guide from some appropriate questions which are in line with the research material. Meanwhile, the interviewees here are the respondents consisted of the Village Secretary who represents the village staff in every sub-district, Village Consultative Institution, sub-district staffs, and the local staffs who handle the village.

\subsubsection{Secondary Data}

The secondary data is a data gotten from the reports, books, notes, that have a strong relationship with the problem in question. For the examples are like the data from documentation related to the Village Government Administration in Bekasi District.

\subsubsection{Data Collection Technique}

- Library Research by using the library as a tool in collecting the data, learning the documentation, and books as reference

- Field Work Research. It is research done directly in the field by using some techniques below Observasion, Interview, and Documentation

\subsubsection{Data Analyze Technique}

Qualitative data is the source of extensive and solid-based exposure and contains information about the processes that occur in the local scope, the author uses data analysis techniques Miles and Huberman (2007) and the following is a picture of data analysis:

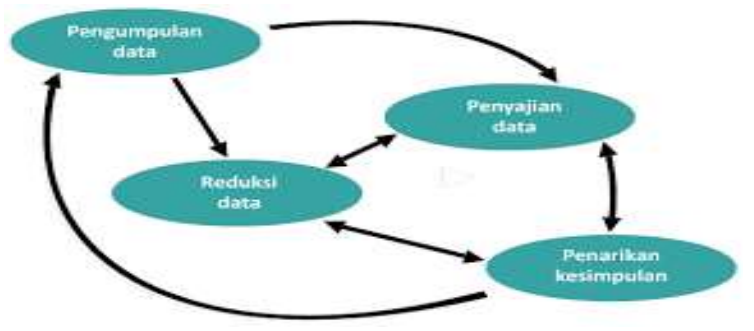


Page: 351-361 ISBN: 978-602-6 988-75-1

Web Jurnal Online: jurnal.unmuhjember.ac.id

By: Rina Susanti Hartono

The Village Government Administration Implementation In Supporting Village

Community And Development Service In Bekasi District

\section{DISCUSSION}

\subsection{Implementation Concept}

Implementation in the Indonesian Language Dictionary described as the application. It means that something that is done or implemented is the designed curriculum to be fully implemented. Based on the information from Usman T $(2002 ; 70)$, implementation is sourced in the activity, action, or mechanism of a system. Implementation is not limited as an actor, but a well-planned work and to reach the activity aim.

Implementation is an expansion of activities that mutually adjust the interaction process between objectives and actions to reach out and need an implementing network, effective bureaucracy (Guntur Setiawan, 2004: 39). Meanwhile, according to information from Hanifa Harsono (2002: 67), implementation is a process to implement policies from politics into administration; the Policy development in improving a program. Implementation is one part of the overall stage. Implementation has a role in governance and in services implemented in every organization; the Policy development in improving a program.

Implementation according to information from Kadir in his book Information system design Andi (2003: 23), implementation is an activity carried out to test the data and realize the system obtained from the selection work. Implementation is one part of the stages of the whole. Implementation has a role in government administration and in services carried out in each organization; the Development of intelligence in improving a program.

\subsection{The Administration Concept of Village Government}

Administration in the Latin Language is $\mathrm{Ad}=$ Intensive and Ministrare = serving, helping, fulfilling. Administration refers to work or effort to help, serve, direct, or organize all works in order to get an aim. Meanwhile, Administration in the Dutch Language is administrative that means the administration in a narrow meaning. It means a work or an office administration (taking notes, typing, and many more again).

Meanwhile, in the English Language, Administration is the coordination process between two people or more based on certain rationality to reach the shared goals that have been determined (Siagian P.1973). So, the administration is the organization of work that is done by the people together to get an aim that has been determined before. Based on S.P Siagian, some indicators in the administration are as follows:

1. It is done by two people or more

2. There is an aim

3. There is cooperation

Based on the information from Law No. 30 of 2014 concerning Government Administration writes that government administration is a system (such as in the collection of decisions and/or government officials). Meanwhile, according to information from the Minister of Home Affairs Regulation No. 47 of 2016 concerning to the Village Government Administration, namely the whole process of working data and information about village governance in the village register book. Village Government 
Page: 351-361 ISBN: 978-602-6 988-75-1

Web Jurnal Online: jurnal.unmuhjember.ac.id

By: Rina Susanti Hartono

The Village Government Administration Implementation In Supporting Village

Community And Development Service In Bekasi District

Administration according to the Minister of Internal Affairs Regulation Number 47 of 2016 Chapter V Article (2) shall be elaborated among other things:

1.The General Administration is the recording data and information about the job of the village government in the general administration book. It is consisted of:
a. The Village Regulation Data Book
b. The Village's head decision data book
c. The Village's land data book
d. The Village Government staffs data book
e. The Village Land Book
f. The Village legal Land Book
g. The Agenda Book
h. The Expedition Book
i. The Village Gazete Book.

2. The Population Administration is a data and information registration activity about the residents and mutation of the residents in the population administration book. It consists of:
a. The population's master data book
b. The population's mutation data book
c. The population number of recapitulation data book
d. The temporary citizen data book

3. The Financial Administration is the administration of data recording job and information about the Village financial management in the financial administration book. It consists of:
a. Estimated book of receipt
b. Book estimates of development spending
c. General cash book
d. Cash development expenditure book

4. The establishment administration is the data registration activity and the establishment's information that will and has been done in the establishment administration book. It consists of:
a. The establishment plan book
b. The establishment work book
c. Project inventory book
d. The establishment of cadres' book

5. The other administration (Information about BPD) consists of:
a. BPD Program Book
b. BPD Data decision book
c. BPD Employment Data Book
d. BPD activity book
e. BPD shipment book 
Proceeding ICOGISS 2019

Page: 351-361 ISBN: 978-602-6 988-75-1

Web Jurnal Online: jurnal.unmuhjember.ac.id

By: Rina Susanti Hartono

The Village Government Administration Implementation In Supporting Village

Community And Development Service In Bekasi District

\subsection{The Village Government Administration Implementation in Bekasi District}

As stated in Law Number 6 of 2014 concerning Villages, what is meant by Village is traditional villages and villages or named by other names, hereinafter referred to as Villages, are legal community units that have district boundaries that are authorized to organize and administer Government Affairs, the interests of the local community according to community initiatives, origin rights and / or traditional rights that are declared and respected in the system of government of the Unitary State of the Republic of Indonesia. Understanding the village from a social point of view can be interpreted as a community in a particular geographical unit and between them know each other well with a relatively homogeneous pattern of life and do not depend directly on nature. Therefore, villages are associated as a society that lives simply in most sectors of agriculture, has strong social ties, customs and traditions, and low levels of education (Juliantara, 2005: $18)$.

Based on Law No. 6 of 2014 concerning Villages, in Article 2 paragraph (1) it is stated that the village is formed on the initiative of the community by observing the village's original rights and the social situation of the local community. In paragraph (2) it is written that village formation must fill the following conditions: population, area, work area, village apparatus, and government facilities and infrastructure.

In national development, village development plays a very urgent role because the village is the lowest government structure in the Indonesian government system. Each type of national development policy certainly leads to rural development because Indonesia's development will not succeed without going through the development and acceleration of rural development, and it can be said that Indonesia's future lies and depends on success in village development and empowerment. Next in Permendegra no 47 of 2016 concerning Village Government Administration article 4 that what is meant by:

(1) The Management of Village administration as referred to in Article 3 is carried out t through:

a. Orderly recording data and information in village register books; and

b. Development of village register books is needed as well as organizing reporting in accordance with statutory provisions.

(2) Implementation and development of Village Government Administration through the orderly recording of data and development of Village register books as referred to in paragraph (1) adjusted to the needs, the level of development of the Village administration, and the complexity of the problems encountered in recording data and information on various activities.

Furthermore, the relationship with the implementation of the village administration the administration in Bekasi Regency has not yet completed most of the five administrative administrations that must be applied in each of its villages, especially development administration. This has made it difficult to know how the development process in the village has been carried out both in the form of government programs, development programs of the Province, development programs from the District and City, development programs carried out by the village itself and development that has been carried out independently. The government administration, in general, is still incomplete 
Page: 351-361 ISBN: 978-602-6 988-75-1

Web Jurnal Online: jurnal.unmuhjember.ac.id

By: Rina Susanti Hartono

The Village Government Administration Implementation In Supporting Village Community And Development Service In Bekasi District

in having books that must be owned by every village. This condition causes difficulties in inventorying shortcomings and strengths and the potential advantages that exist in the village.

\section{CONCLUSION AND SUGGESTION}

\subsection{Conclusion}

1. Administration of village government in its implementation will bring good achievements through success in the field of village administration if it is balanced with the completeness of the data as various forms of service processes and development processes by villages in Bekasi Regency.

2. This organization can be seen through the involvement of all government instruments from the district level, sub-district and village officials in the administration process to support the service process and development found in rural communities in Bekasi Regency.

3. The process of applying administrative administration is quite good where most of the village governments have undergone this field which is equipped with supporting databooks.The existing communication relationship is very good because the village government always fosters communication with village officials and fosters good relations with the community.

4. The process of implementing the Administration of development is still very lacking because it has not been supported by data on the results of development originating from various village funding sources.

\subsection{Suggestion}

1. In the administration of the village administration, there is still a need for direct guidance to each village in order to create more targeted communication to achieve the desired goals.

2. The communication process developed is maintained so that togetherness in the administration of the village government is maintained.

3. In the process of improving the performance of the village administration in the future, it is necessary to collaborate with parties who can assist in sharpening the implementation of village government administration through the use of technology, namely utilizing the village information system which is directly implemented through the village website. 
Proceeding ICOGISS 2019

Page: 351-361 ISBN: 978-602-6 988-75-1

Web Jurnal Online: jurnal.unmuhjember.ac.id

By: Rina Susanti Hartono

The Village Government Administration Implementation In Supporting Village

Community And Development Service In Bekasi District

\section{REFERENCE}

A.W. Widjaja. 2002. Komunikasi dan Hubungan Masyarakat. Jakarta : PT. Bumi Aksara.

Agung, Kurniawan. 2005. Transformasi Pelayanan Publik. Yogyakarta. Penerbit Pembaharuan.

Ahmad Farouk,M Yasin dkk, 2015, Law Annotation No.6 tahun 2014 about Village, PATTIRO, Jakarta.

Arikunto, Suharsimi. (2005). ManajemenPenelitian. Jakarta: RinekaCipta.

Hanifah Harsono, 2002, Implementasi Kebijakan dan Politik, Jakarta, Rineka Cipta.

Haryono, Paulus, 2007. Sosiologi Kota Untuk Arsitek. Penerbit Bumi Aksara, Jakarta.

Juliantara, Dadang. 2005. Peningkatan Kapasitas Pemerintah Daerah dalam Pelayanan Publik. Yogyakarta: Pembaruan.

Decree of the Minister of Administrative Reform number 63/KEP/M.PAN/2003 about the Common Guidelines of Public Service Management

Minister of Home Affairs Number 47 Tahun 2016 about the village government administration.

Miles, Matthew B. and A. Michael Huberman, 2007, Qualitative Data Analysis (translation), Jakarta : UI Press.

Pasolong, Harbani. 2007, Teori Administrasi Publik, Alfabeta, Bandung.

Decree of Minister of Home Affairs number 32 Year 2006 Village Administration Guideline.

Decree of Minister of Home Affairs number 47 years 2016 about the village government administration

Minister Regulation number 16 Year 2018 about priority of use Government Regulations Number 72 Year 2005 about Village Government.

Minister Regulations number 16 Year 2018 about the priority use of the village funds.

Regulations of Minister of Home Affairs No. 47 Year 2016 about the village government administration

Setiawan, Guntur. (2004). Implementasi Dalam Birokrasi Pembangunan. Bandung:Remaja Rosdakarya Offset.

Sinambela, Lijan Poltak.dkk. 2006. Reformasi Pelayanan Publik. Teori, Kebijakan dan Implementasi, Bumi Aksara. Jakarta.

Syafiie, Inu Kencana. 2003. Sistem Administrasi Negara Republik Indonesia. Jakarta : PT. Bumi Aksara. 
Page: 351-361 ISBN: 978-602-6 988-75-1

Web Jurnal Online: jurnal.unmuhjember.ac.id

By: Rina Susanti Hartono

The Village Government Administration Implementation In Supporting Village

Community And Development Service In Bekasi District

Indonesian Republic Law number 6 Year 2014 about Villages

Laws Number 30 Year 2014 about the government administration

Laws Number 6 Year 2014 about village

Laws Number 32 Year 2004 about the regional government

Laws Nomor 23 Tahun 2014 about the regional government 